This is the author's final, peer-reviewed manuscript as accepted for publication. The publisher-formatted version may be available through the publisher's web site or your institution's library.

\title{
Summer cover crops fix nitrogen, increase crop yield and improve soil-crop relationships
}

Humberto Blanco-Canqui, M. M. Claassen, and D. R. Presley

\section{How to cite this manuscript}

If you make reference to this version of the manuscript, use the following information:

Blanco-Canqui, H., Claassen, M. M., \& Presley, D. R. (2012). Summer cover crops fix nitrogen, increase crop yield and improve soil-crop relationships. Retrieved from http://krex.ksu.edu

\section{Published Version Information}

Citation: Blanco-Canqui, H., Claassen, M. M., \& Presley, D. R. (2012). Summer cover crops fix nitrogen, increase crop yield and improve soil-crop relationships. Agronomy Journal, 104(1), 137-147.

Copyright: Copyright $\odot 2012$ by the American Society of Agronomy

Digital Object Identifier (DOI): doi:10.2134/agronj2011.0240

Publisher's Link:

https://www.agronomy.org/publications/aj/articles/104/1/137?highlight=

This item was retrieved from the K-State Research Exchange (K-REx), the institutional repository of Kansas State University. K-REx is available at http://krex.ksu.edu 
Summer Cover Crops Fix Nitrogen, Increase Crop Yield and Improve Soil-Crop

\section{Relationships}

${ }^{1}$ Humberto Blanco-Canqui, ${ }^{2}$ M.M. Claassen, and ${ }^{3}$ D.R. Presley

${ }^{1}$ H. Blanco-Canqui, Kansas State Univ., Dept. of Agronomy, Agricultural Research Center-Hays, 1232 240th Ave., Hays, Kansas 67601-9228. Phone: (785) 625-3425 Ext 215. Fax: 785-6234369.; ${ }^{2}$ M.M. Claassen, Professor (Retired), Kansas State Univ., 202 S. Roupp, Hesston, KS 67062. ${ }^{3}$ D.R. Presley, Agronomy Dep., Kansas State Univ., Manhattan, KS 66506.

*Corresponding author (hblanco@ksu.edu) 


\begin{abstract}
Impact of cover crops (CCs) on winter wheat [Triticum aestivum (L.)] and grain sorghum [Sorghum bicolor (L.) yields is not well understood. We assessed crop yield and its relationships with CC-induced changes in soil properties for a 15-yr CC experiment in wheat-sorghum rotation at $0,33,66$, and $100 \mathrm{~kg} \mathrm{ha}^{-1}$ of $\mathrm{N}$ application in south central Kansas. Hairy vetch (Vicia villosa Roth) was used as a winter CC from 1995 to 2000, while sunn hemp (SH; Crotalaria juncea L.) and late-maturing soybean (LMS; Glycine max L.) were used as summer CCs in notill from 2002 to 2008. Summer CCs increased crop yields particularly at low rates of N application. At $0 \mathrm{~kg} \mathrm{~N} \mathrm{ha}^{-1}$, SH increased sorghum yield by 1.18 to 1.54 times, while wheat yield increased by 1.60 times in the first year (2004) after CC establishment relative to non-CC plots. At $66 \mathrm{~kg} \mathrm{~N} \mathrm{ha}{ }^{-1}$, SH had no effects on sorghum yield, but it increased wheat yield in three of four years. Cover crops increased near-surface soil total $\mathrm{N}$ pool by $270 \mathrm{~kg} \mathrm{ha}^{-1}$. Crop yield increased with the CC-induced decrease in soil maximum compactibility (soil’s susceptibility to compaction) and soil temperature, and increase in soil aggregate stability, soil organic C (SOC) and total $\mathrm{N}$ concentration, and soil water content, particularly at $0 \mathrm{~kg} \mathrm{~N} \mathrm{ha}^{-1}$. Principal component analysis (PCA) selected soil compactibility and total $\mathrm{N}$ as the best yield predictors. Inclusion of summer legume CCs in no-till fixes $\mathrm{N}$, increases crop yield and improves soil-crop relationships.
\end{abstract}

Abbreviations: CCs, cover crops; LMS, late-maturing soybean; SOC, soil organic carbon; SH, sunn hemp; PCA, principal component analysis; PCs, principal components

Understanding CC impacts on soil-crop relationships is essential to the development of sustainable cover cropping systems. Benefits of CCs for providing additional biomass input, 
reducing soil erosion, and promoting nutrient cycling are well recognized, but their impacts on subsequent crop yields and quantitative relationships with soil properties such as physical properties deserve further scrutiny. Because performance of CCs may vary with CC type, soil type, tillage management, and climate, a site-specific assessment of soil-crop relationships under different CCs is warranted.

Cover crops may or may not increase yields of subsequent crops (Kuo and Jellum, 2000; Andraski and Bundy, 2005; Balkcom and Reeves, 2005; Olson et al., 2010). Their impacts on subsequent crop yields and soil properties most likely depend on precipitation input, CC species, growing season (summer versus winter CCs), amount of biomass return, tillage management, and length of CC management. Under favorable climatic conditions, high-biomass producing and high-N fixing summer or tropical legume CCs such as SH may have more rapid and greater effects on increasing crop yields and improving soil properties than CCs with low biomass input.

Because of high biomass input, summer legume CCs can provide an effective protective cover to soil and supply significant amounts of $\mathrm{N}$ to subsequent crops (Mansoer et al., 1997; Schomberg et al., 2007). Balkcom and Reeves (2005) reported that SH produced 7.6 Mg ha-1 of biomass with $144 \mathrm{~kg} \mathrm{ha}^{-1}$ of $\mathrm{N}$ concentration in the first two years and increased corn yield by 1.2 $\mathrm{Mg} \mathrm{ha}^{-1}$ relative to non-CC plots in two of three years of management on a loamy sand in AL. Cherr et al. (2006) observed that SH produced 8.0 $\mathrm{Mg} \mathrm{ha}^{-1}$ of biomass with $146 \mathrm{~kg} \mathrm{ha}^{-1}$ of N in $12 \mathrm{wk}$ in the first year and $12.2 \mathrm{Mg} \mathrm{ha}^{-1}$ of biomass with $172 \mathrm{~kg} \mathrm{ha}^{-1}$ of $\mathrm{N}$ in 14 wk in the second year on a sandy soil in northern FL. More studies along these lines are needed to better understand summer CC effects on biomass input, N supply, and crop yields.

Summer legume CCs can also improve soil properties (Carof et al., 2007). Blanco-Canqui et al. (2011) reported that SH and LMS when used as summer CCs reduced soil's susceptibility to 
compaction and increased wet aggregate stability, water infiltration, earthworm population, and SOC concentration. These CC-induced changes in soil properties may concomitantly benefit yields of subsequent crops. While CCs may not always increase crop yields and improve properties in all soils (Andraski and Bundy, 2005; Olson et al., 2010), we hypothesize that CCs will increase crop yields if soil physical properties improve and SOC and soil N concentration increase with cover cropping.

Many have studied the effect of soil properties on crop yields (Kravchenko and Bullock, 2000; Kaspar et al., 2004; Cox et al., 2005; Hao et al., 2010), but little data are available on the changes in soil physical parameters and SOC concentration affecting crops yields in intensively managed no-till cropping systems. For example, soil physical properties may affect crop growth and yield by influencing aeration, water transmission and retention, heat flux, organic matter decomposition, $\mathrm{N}$ mineralization, nutrient release, and microbial activity. Some physical properties such as compaction may directly affect plant growth, while others such as aggregate stability may have indirect effects. The objectives of this study were to assess no-till summer CC effects on subsequent wheat and sorghum yield and study their relationships with soil physical properties, SOC, and soil total N concentration on an Udic Argiustoll in south central Kansas. 


\section{MATERIALS AND METHODS}

\section{Description of the Experiment}

Crop yield data and soil properties for this study were collected from a long-term (15 yr) experiment of CCs under no-till winter wheat and grain sorghum rotation at Hesston, KS (38.14 ${ }^{\circ} \mathrm{N}$ lat. and $97.43^{\circ} \mathrm{W}$. long.). The CC experiment was initiated in 1995 and terminated in 2009. The soil was a Geary silt loam (fine-silty, mixed, superactive, mesic Udic Argiustolls) with a $<3 \%$ slope. Thirty-year average annual precipitation for the experimental site is $839 \mathrm{~mm}$. The CC experiment consisted of a factorial combination of three CC treatments and four $\mathrm{N}$ rates. The resulting 12 treatments were laid out on a randomized complete block design with four replicates. Plot size was 6 by $13.5 \mathrm{~m}$. The main rotation was a winter wheat-grain sorghum in which wheat was no-till planted into grain sorghum stubble in the fall and harvested in June of the next year. The CCs were planted after wheat; and grain sorghum was planted in June of the following year. Nitrogen at rates of $0,33,66$, and $100 \mathrm{~kg} \mathrm{~N} \mathrm{ha}^{-1}$ as urea (46-0-0) was applied to both wheat and sorghum.

Between 1995 and 2000, hairy vetch was used as a winter CC. The three CC treatments during this period were hairy vetch early termination, hairy vetch late termination, and control. Beginning in 2002, SH and LMS as summer CCs were assigned to the plots where hairy vetch treatments had been in place and the remaining plots retained the no-CC treatment. The existing factorial arrangement of $\mathrm{N}$ rates also was retained. Wheat under no-till was grown without fertilizer across all plots in the transition year between 2000 and 2002. The summer CCs were planted in early July after wheat harvest in the corresponding years except in 2006 when they were planted in early August due to late seed arrival. The summer CCs were planted in $20 \mathrm{~cm}$ row spacing and terminated in September or October with a crop roller followed by herbicide 
application. The CC residues were neither hayed nor removed from the plots. The summer CCs including the no-CC treatment were all managed under no-till. Aboveground residue yield of each CC was determined by harvesting $0.30 \mathrm{~m}^{2}$ area in each plot before termination. Samples were oven-dried at $60^{\circ} \mathrm{C}$ and weighed to determine residue yield. The summer CCs were last grown in the summer of 2008 followed by grain sorghum in 2009. Additional information on CC management history including tillage management, planting date, seeding rate, and termination date is given in Table 1.

Grain sorghum was planted at a rate of 103,780 seeds ha $^{-1}$ in $76 \mathrm{~cm}$ row spacing in late May or June (Table 2). Plots received $18 \mathrm{~kg} \mathrm{P} \mathrm{ha}^{-1}$ as triple super-phosphate (0-46-0) at sorghum planting, and $\mathrm{N}$ was broadcast before planting or injected after planting at the rates specified earlier. Wheat was planted at a rate of $100 \mathrm{~kg} \mathrm{ha}^{-1}$ in $20 \mathrm{~cm}$ row spacing in October or early November (Table 2). Plots received $17 \mathrm{~kg} \mathrm{P} \mathrm{ha}^{-1}$ at wheat planting, and $\mathrm{N}$ was broadcast before planting at the corresponding rates. Wheat and sorghum were harvested at maturity from all the plots (Table 2). Grain sorghum was harvested in late September, October or early November, while wheat was harvested in June or early July. Grain yield was expressed at $125 \mathrm{~g} \mathrm{~kg}^{-1}$ of moisture content. Weeds were controlled according to cultural practices in the region and presented no significant effect on plot moisture or crop competition in this study. Weeds during pre-emergence, row crop season, and between crops were controlled with Roundup Ultra Max II and atrazine (2-chloro-4-ethylamino-6-isopropylamino-1,3,5-triazine) plus metolachlor [2chloro-N-(2-ethyl-6- methylphenyl)-N-(2-methoxy-1-methylethyl) acetamide].

In the winter wheat-sorghum system utilized, wheat was planted after the fall harvest of grain sorghum as indicated earlier. In this system, both grain sorghum harvesting conditions as well as post-harvest soil moisture conditions dictated wheat planting dates. In the study region, winter 
wheat is typically planted in October. Continuous wheat is often planted earlier in the month than for wheat immediately following grain sorghum or other row crop. Late October wheat plantings can be somewhat disadvantageous but not uncommon in wheat-sorghum rotations. Grain sorghum is normally planted in June, but, in some cases, it is planted in late May. In this study, summer CCs did not significantly interfere with typical wheat and sorghum planting times in the region. Thus, planting dates shown in Table 2 are similar to those for commonly grown annual wheat and sorghum in the region. Further details on the CC and wheat-sorghum rotation management for this experiment are presented by Claassen (2009) and Blanco-Canqui et al. (2011).

\section{Experimental Data}

Yield data for wheat and grain sorghum collected for all rotation cycles under the two summer CCs were studied. Grain sorghum yield data were collected in 2003, 2005, 2007, and 2009, while wheat yield data were collected in 2004, 2006, and 2008. For the study of soil-crop relationships, yield data from the last year of the experiment for each crop were used. Data on soil physical properties, and SOC and total N concentration collected in spring 2010 and reported in a companion study by Blanco-Canqui et al. (2011) for the same experiment were used. Twelve soil properties including bulk density, cone index, Proctor maximum bulk density (a parameter of soil maximum compactibility), amount of macroaggregates ( $>250 \mu \mathrm{m}$ diam.), mean weight diameter of aggregates, log-transformed saturated hydraulic conductivity, total porosity, volumetric water content at -33 and $-1,500 \mathrm{kPa}$ matric potentials, field volumetric water content, daytime soil temperature measured in spring, and SOC and $\mathrm{N}$ concentration measured for the 0to 7.5-cm soil depth were used. Data from plots receiving 0 and $66 \mathrm{~kg} \mathrm{~N}^{-1}$ were used for this study. The plots without $\mathrm{N}$ fertilization $\left(0 \mathrm{~kg} \mathrm{~N}^{-1}\right)$ were selected to assess the independent 
effects of CCs on soil-crop relationships without confounding effects of inorganic $\mathrm{N}$ application. The plots under $66 \mathrm{~kg} \mathrm{~N} \mathrm{ha}^{-1}$ of $\mathrm{N}$ application were chosen to reflect the typical rate of $\mathrm{N}$ fertilization used for wheat-sorghum rotations in the region. Protocols of field and lab measurements of soil properties were discussed by Blanco-Canqui et al. (2011).

\section{Data Analysis}

Wheat and sorghum yield data were analyzed by PROC MIXED (SAS Institute, 2011). Because cover crop $\times \mathrm{N}$ rate $\times$ year interaction for both crops was highly significant, statistics on yield for each crop were performed by year. Cover crops and $\mathrm{N}$ rates were considered as fixed factors, while replicate was a random factor. Means among treatments were compared using LSMEANS in PROC MIXED. PROC CORR in SAS was used to study correlations between crop yield and the twelve soil properties. Principal component analysis (PCA) in SAS was performed to group highly correlated soil properties, eliminate multicollinearity among soil properties, and select the best predictors of crop yield. Correlations and PCA were performed by crop and N rate. Based on the PCA, principal components (PCs) with eigenvalues $>1$ were retained using the Kaiser criterion. The PCs were then subjected to varimax rotation using the PROC FACTOR in SAS. Rotated scores and communality estimates were used to determine soil properties with the highest factor loading within each PC. The soil property with the highest loading from each PC was selected to develop predictive equations for each crop and $\mathrm{N}$ rate using PROC STEPWISE in SAS. Statistical differences were computed at the 0.05 probability level unless specifically mentioned. 


\section{RESULTS AND DISCUSSION \\ Cover Crop Height and Residue Yield}

Monthly and annual mean precipitation during the summer CC study is given in Table 3. Year to year and monthly fluctuations in precipitation are reflected in the yield performance of CCs as well as the main crops (Tables 3 and 4; Figs. 1 and 2). Despite some really dry years (i.e., 2006; Table 3), summer CCs afforded sufficient time between fall termination and succeeding grain crop for soil moisture replenishment. In this experiment, summer CCs were never terminated early. Winter wheat tended to depend more on timely fall precipitation than sorghum since wheat followed as a double crop after sorghum. Wheat yield was somewhat low but not uncommon for this region (Fig. 2).

Cover crop height and residue yield between the two summer CCs differed (Table 4). The N fertilization of wheat and sorghum (main crops) at four different rates had no effect on CC height and residue yield in any year. Cover crop $\times$ year interaction was significant for both CC height and residue yield. Sunn hemp height was greater than LMS height by 2.3 times in 2002, 3.1 in 2004, 2.9 in 2004, and 2.7 in 2008 (Table 4). The SH height ranged from 1.32 to $2.44 \mathrm{~m}$, while LMS height ranged from 0.46 to $0.96 \mathrm{~m}$. In 2006, CCs were the shortest and yielded the lowest of the four years, attributed to late CC planting and lower precipitation. Summer CCs in 2006 were planted one month later than in other years due to delay in seed arrival. Also, 2006 was the driest year during the 15-year period in which precipitation was about $74 \%$ of the long-term average precipitation in the region (Table 3).

Residue yield between SH and LMS differed in all years except in 2002 (first year of summer CC establishment; Table 4). In 2002, SH produced, averaged across $\mathrm{N}$ rates, $7.88 \mathrm{Mg} \mathrm{ha}^{-1}$ of residues and LMS produced 8.76 $\mathrm{Mg} \mathrm{ha}^{-1}$. Despite cumulative precipitation in July and August in 
2002 was slightly below normal, both summer CCs established well. In 2004, precipitation in July was above normal but August and September were drier than usual. During this year, SH produced 7.16 $\mathrm{Mg} \mathrm{ha}^{-1}$ of residues and LMS produced 4.73 $\mathrm{Mg} \mathrm{ha}^{-1}$. In 2006, SH yielded 4.65 $\mathrm{Mg} \mathrm{ha}^{-1}$ of residues and LMS yielded 2.99 $\mathrm{Mg} \mathrm{ha}^{-1}$. In 2008 (last rotation cycle), SH produced 10.19 $\mathrm{Mg} \mathrm{ha}^{-1}$ of residues and LMS produced 9.10 $\mathrm{Mg} \mathrm{ha}^{-1}$. This year, SH yielded more than in previous years, probably due to the greater precipitation input $(347 \mathrm{~mm})$ in July, August and September compared with the same months in 2002 (162 mm), 2004 (243 mm), and 2006 (237 mm; Table 3).

Results indicate that summer CCs, particularly SH, can return significant amounts of residues. The amount of residue input is high in spite of fluctuations in precipitation input from year to year. Results also indicate that summer CCs produce large amounts of residues in a short period of about 12 weeks. The high aboveground residue input can have beneficial effects on crop yields and soil properties as discussed later. The increased height of SH may also be beneficial for shading and smothering weeds. Similar results of high residue input from SH were reported in other regions (Mansoer et al., 1997; Balkcom and Reeves, 2005; Cherr et al., 2006; Schomberg et al., 2007).

\section{Cover Crop Effects on Grain Sorghum and Winter Wheat Yield}

Cover crops and $\mathrm{N}$ application rates increased sorghum (Fig. 1) and wheat (Fig. 2) yield. The $\mathrm{CC} \times \mathrm{N}$ rate interaction was significant in some years (Table 5). Sunn hemp increased sorghum and wheat yield following the first year of SH establishment particularly in non-fertilized plots, suggesting that summer CCs may have rapid effects on increasing yields of subsequent crops. At $0 \mathrm{~kg} \mathrm{~N} \mathrm{ha}^{-1}$, SH increased sorghum yield by 1.18 times in 2003 (first rotation cycle), 1.54 times in 2005, 1.32 in 2007, and 1.43 in 2009 relative to non-CC plots. Late-maturing soybean did not 
increase sorghum yield in 2003, but it increased sorghum yield at $0 \mathrm{~kg} \mathrm{~N} \mathrm{ha}^{-1}$ in 2005 and at all levels of $\mathrm{N}$ application except at $100 \mathrm{~kg} \mathrm{~N} \mathrm{ha}^{-1}$ in 2009. Both SH and LMS increased wheat yield in 2004 (first rotation cycle after summer CC establishment). At $0 \mathrm{~kg} \mathrm{~N} \mathrm{ha}^{-1}$, SH and LMS increased wheat yield by 1.70 times in 2004, but they had no effects on yield in 2006 and 2008 . Wheat yield was low in 2006 due to the reduced precipitation input compared with other years (Table 3).

Sunn hemp increased sorghum yield more than LMS in 2003 at $100 \mathrm{~kg} \mathrm{~N} \mathrm{ha}^{-1}$ and 2007 at 0 $\mathrm{kg} \mathrm{N} \mathrm{ha}^{-1}$. At $33 \mathrm{~kg} \mathrm{~N} \mathrm{ha}^{-1}$, SH also increased sorghum yield in 2005 by 1.18 times and 2009 by 1.10 times, whereas LMS increased yield, at this $\mathrm{N}$ level, only in 2009. At the same $\mathrm{N}$ level, SH also increased wheat yield by 1.17 times in 2004 and 1.25 in 2008. At $66 \mathrm{~kg} \mathrm{~N} \mathrm{ha}^{-1}$, SH did not increase sorghum yield, but it increased wheat yield in all years except in 2003 (Table 1). At 100 kg N ha ${ }^{-1}$, CCs did not increase crop yields except in 2003 where SH increased sorghum yield (Table 1). These results suggest that summer CC effects on increasing crop yield decreased with increasing rates of $\mathrm{N}$ application in most years (Fig. 1).

The differences in sorghum yield between SH and non-CC plots at $0 \mathrm{~kg} \mathrm{~N} \mathrm{ha}^{-1}$ tended to increase gradually with time (Fig. 1). Compared with non-CC plots, SH increased sorghum yield by $0.57 \mathrm{Mg} \mathrm{ha}^{-1}$ in 2003 (first year of rotation) and by $2.12 \mathrm{Mg} \mathrm{ha}^{-1}$ in 2009 (last year of rotation). These results suggest that the benefits of CCs for increasing sorghum yield can be greater in the long term possibly due to gradual accumulation in soil nutrients ( $\mathrm{C}$ and $\mathrm{N}$ ) and improvement in soil physical properties. 
Inorganic N fertilization increased both sorghum and wheat yield except for sorghum in 2003 (Table 5; Fig. 1 and 2). In most years, crop yields increased following a quadratic function as rates of $\mathrm{N}$ application increased. Nitrogen application above $66 \mathrm{~kg} \mathrm{~N}^{-1}$ had lesser effects on increasing crop yield than at or below $66 \mathrm{~kg} \mathrm{~N} \mathrm{ha}^{-1}$. Non-CC plots responded more to inorganic fertilization than plots with CCs in most years. Indeed, compared with non-fertilized plots, 100 kg N ha ${ }^{-1}$ increased sorghum yield by about 1.6 times in non-CC plots, whereas it increased sorghum yield only by 1.18 times in plots with SH and LMS (Fig. 1). Likewise, $100 \mathrm{~kg} \mathrm{~N} \mathrm{ha}^{-1}$ increased wheat yield by about 5.1 times in non-CC plots, whereas it increased wheat yield only by about 3.45 times in plots with SH and LMS (Fig. 1). Furthermore, plots with LMS for sorghum tended to respond less to $\mathrm{N}$ application at rates above $33 \mathrm{~kg} \mathrm{ha}^{-1}$ than plots with SH. For the same experiment, Claassen (2009) reported SH residues contained $23.7 \mathrm{~g} \mathrm{~kg}^{-1}$ of $\mathrm{N}$ while LMS residues had $31.1 \mathrm{~g} \mathrm{~kg}^{-1}$ of $\mathrm{N}$. Thus, because of lower C:N ratio, soybean residues probably decomposed much faster than $\mathrm{SH}$ residues, providing more $\mathrm{N}$ to the subsequent crop and offsetting benefits from inorganic $\mathrm{N}$ fertilization.

Wheat appeared to be more responsive to $\mathrm{N}$ application than sorghum. For example, from 0 to $100 \mathrm{~kg} \mathrm{~N} \mathrm{ha}^{-1}$, wheat yield in non-CC plots increased by 4.3 times in 2004, 7 in 2006, and 4 in 2008, while sorghum yield in the same plots increased only by 2.0 times in 2005 and 1.50 in 2007 and 2009. Similar greater wheat response to application N was observed in plots under SH and LMS. The greater wheat yield increase with $\mathrm{N}$ fertilization suggests: 1 ) less CC-derived $\mathrm{N}$ may have been available for wheat than for sorghum, which succeeded CCs prior to wheat, 2) sorghum may scavenge more $\mathrm{N}$ from the soil than wheat, and 3) differences in soil water content between sorghum (spring) and wheat (fall) planting may have affected crop response to $\mathrm{N}$ application (Table 3). 
The significant and rapid increase in no-till wheat and sorghum yields with the inclusion of CCs shows the potential benefit of CCs for increasing subsequent crop yields in no-till systems. The rapid increase in crop yield with SH agrees with the results from Balkcom and Reeves (2005). Our study indicates that the benefits of CCs for increasing crop yields can be particularly greater at or below $66 \mathrm{~kg} \mathrm{ha}^{-1}$ of $\mathrm{N}$ application (Fig. 1 and 2). These results suggest that CCs may sufficiently supplement applied $\mathrm{N}$ to maintain crop yields in a profitable range all while suppressing weeds, lowering input costs for herbicides and fertilizers, and preserving soil moisture.

\section{Cover Crops and Soil Nitrogen Fixation}

Cover crops and $\mathrm{N}$ application rates increased soil total $\mathrm{N}$ concentration in the 0 - to $7.5-\mathrm{cm}$ soil depth (Fig. 3A-B). The $\mathrm{CC} \times \mathrm{N}$ rate for total $\mathrm{N}$ was not significant. Averaged across the four $\mathrm{N}$ application rates, soil total $\mathrm{N}$ concentration increased by $258 \mathrm{~kg} \mathrm{ha}^{-1}$ under LMS and by $279 \mathrm{~kg}$ ha ${ }^{-1}$ under SH compared with non-CC plots (Fig. 3). These results show that CCs fixed significant amounts of soil $\mathrm{N}$ during the four rotation cycles. The high $\mathrm{N}$ fixation potential of $\mathrm{SH}$ and LMS suggests that these summer legume CCs can supplement $\mathrm{N}$ to main crops and reduce inorganic $\mathrm{N}$ fertilization requirements in this climate. The beneficial effects of summer CCs may be, however, limited or diminished in regions with lower precipitation input.

Crop yield data in Figs. 1 and 2 suggest that summer CCs probably supplement $\mathrm{N}$ at both low and optimum levels of $\mathrm{N}$ application. Fixation of $\mathrm{N}$ through legume CCs may reduce the excessive dependence on inorganic $\mathrm{N}$ fertilizers in this region. It is important to note that this study only reports soil total $\mathrm{N}$. Further research is needed to determine the concentration of readily available or mineralizable $\mathrm{N}$ under CCs for a better understanding of net release or $\mathrm{N}$ contribution to succeeding crops. 
Studies in other regions have also found high $\mathrm{N}$ contribution from tropical legume CCs (Reddy, 1986; Mansoer et al., 1997). Summer CCs return high amount of N-enriched biomass (Wang et al., 2009). Because of their rapid growth and high biomass production and $\mathrm{N}$ fixation, legume summer crops such as SH may supplement $\mathrm{N}$ for subsequent crops and reduce inorganic $\mathrm{N}$ fertilizer use. High $\mathrm{N}$ application rate $\left(100 \mathrm{~kg} \mathrm{~N} \mathrm{ha}^{-1}\right)$ masks benefits of CC-derived soil $\mathrm{N}$ and appears to have limited effects on crop yields (Figs. 1 and 2).

Inorganic $\mathrm{N}$ application had mixed effects on soil total $\mathrm{N}$ (Fig. 3B). Across all CC treatments, $\mathrm{N}$ fertilization at $66 \mathrm{~kg} \mathrm{~N} \mathrm{ha}^{-1}$ increased total $\mathrm{N}$ concentration by $291 \mathrm{~kg} \mathrm{ha}^{-1}$, but $\mathrm{N}$ fertilization at 33 and $100 \mathrm{~kg} \mathrm{~N} \mathrm{ha}^{-1}$ had no effects. While $\mathrm{N}$ application at $100 \mathrm{~kg} \mathrm{ha}^{-1}$ increased wheat and sorghum yield, it did not increase soil total $\mathrm{N}$, indicating large $\mathrm{N}$ application does not increase on soil total $\mathrm{N}$ in spite of increased crop residue input. The effects of high rates of $\mathrm{N}$ application on soil total N has been widely discussed (Mulvaney et al., 2009; Powlson et al., 2009).

While this study did not quantify microbial biomass and activity, Blanco-Canqui et al. (2011) observed that plots with summer CCs had greater number of earthworms (Lumbricus terrestris L.) than plots without CCs. This finding suggests that greater biological activity in plots with CCs may contribute to $\mathrm{N}$ release from CC residues into the soil. Studies have shown that CCderived $\mathrm{N}$ can be readily mineralized through biological activity and made available as nitrates for the subsequent crops with little or no loss of $\mathrm{N}$ through leaching (Jackson, 2000). Fertilizer management (rate and timing) of sorghum and wheat and precipitation input can be critical to optimize the use of CC-derived $\mathrm{N}$.

\section{Cover Crop Effects on Soil-Crop Yield Relationships}

Crop yields were correlated with the CC-induced changes in Proctor maximum bulk density, mean weight diameter of aggregates, SOC and total $\mathrm{N}$ concentration, soil water content, and 
spring soil temperature (Fig. 4A through Fig. 6D) but not with rest of soil properties (data not shown). Crop yield increased with CC-induced decrease in Proctor maximum bulk density (Fig. 4A-B) and soil temperature (Fig. 6C-D) and increase in macroaggregation (Fig. 4C-D), SOC and total N concentration (Fig. 5A-B; Fig. 5C-D), and field soil water content (Fig. 6A-B).

Correlations were stronger at 0 than at $66 \mathrm{~kg} \mathrm{~N} \mathrm{ha}^{-1}$, suggesting that $\mathrm{N}$ fertilization may have offset some beneficial effects of soil properties improved by CCs on crop yields. The strong correlations suggest CCs may contribute to the increase in yields of the subsequent crops by improving soil properties.

The significant influence of Proctor maximum bulk density on crop yields indicates that addition of CCs to no-till may increase yields of subsequent crops, in part, by reducing soil's susceptibility to compaction. As reported in the companion study by Blanco-Canqui et al. (2011), plots in SH and LMS had greater Proctor maximum bulk density than non-CC plots, which indicates that non-CC plots were more susceptible to soil compaction. While other compaction parameters such as bulk density and cone index were not strongly correlated with crop yield, Proctor maximum bulk density was strongly and negatively correlated with sorghum ( $r=$ $\left.0.77^{* * *}\right)$ and wheat $\left(r=-0.82^{* * *}\right)$ yields at $0 \mathrm{~kg} \mathrm{~N} \mathrm{ha}^{-1}$ (Fig. 4A-B). This suggests that Proctor maximum bulk density is a more sensitive compaction parameter to predict crop yield than bulk density and cone index. The adverse effects of soil compaction on crop yields are well recognized. Our results suggest that CC-induced decrease in soil compactibility most likely favored root growth, nutrient uptake, and water, air, and heat flow through the soil, increasing crop yields relative to non-CC plots (Gregorich et al., 2011).

The positive correlation of CC-induced increase in aggregate stability with wheat yield at 66 $\mathrm{kg} \mathrm{N} \mathrm{ha}^{-1}$ suggests that macroaggregation possibly favored root growth and penetration, 
improved nutrient cycling, and enhanced water transmission properties. Across $\mathrm{N}$ levels, mean weight diameter of aggregates, a parameter of aggregate stability, in SH and LMS was 1.8 times greater than in non-CC plots (Blanco-Canqui et al. 2011). Stable aggregates can also contribute to crop production by reducing nutrient loss in runoff (Weil and Magdoff, 2004). Weak aggregates from non-CC plots are easily dispersed by raindrop impacts and eroded along with organic $\mathrm{C}$ and other nutrients. Erosion preferentially removes nutrients near the surface layers.

The strong correlation of SOC on crop yields indicates that increase in SOC concentration with the addition of CCs is another determinant for the increase in crop yields. The SOC concentration averaged across SH and LMS was 1.25 times greater than in non-CC plots in the 0- to 7.5-cm soil depth (Blanco-Canqui et al., 2011). Regression equations suggest that $1 \mathrm{~g}$ increase of SOC concentration per kg of soil increased sorghum yield by $0.36 \mathrm{Mg} \mathrm{ha}^{-1}$ (Fig. 5A) and wheat yield by $0.04 \mathrm{Mg} \mathrm{ha}^{-1}$ at $0 \mathrm{~kg} \mathrm{~N} \mathrm{ha}^{-1}$ (Fig. 5B). While SOC effects on crop yields are often confounded with other effects of CCs on soil properties, our results suggest that the increase in SOC concentration is probably of the main factors by which CCs increase yields of succeeding crops.

The SOC does not only stimulate crop growth through nutrient cycling but also through improvement in soil physical properties. It reduces soil compactibility, promotes macroaggregation, increases water retention capacity, increases water infiltration, and absorbs and filters nutrient loss in runoff (Rawls et al., 2003; Weil and Magdoff, 2004). Our results support recent emphasis on enhancing the SOC pool in agricultural ecosystems for increasing crop yields, improving soil properties, and addressing food insecurity (Lal, 2011). Similar to SOC, the strong positive correlation of yield with soil total $\mathrm{N}$ concentration indicate that CCs can increase crop yields by supplying N (Fig. 5C-D). 
The positive correlation of wheat and sorghum yield with CC-induced increase in soil water content (Fig. 6A-B) and negative correlation with CC-induced decrease in spring soil temperature (Fig. 6C-D) corroborate the critical importance of soil water and temperature for crop production. It is important to clarify that, in this study, soil water content and soil temperature were measured only once during spring time (one and half years after CC termination). The significant correlations show nonetheless the influence of CC residue mulch on soil water and temperature. In this study, soils mulched with CC residues had greater volumetric water content and lower temperature in spring than soils without CCs (Blanco-Canqui et al., 2011). The increased soil warming in soils without CCs probably accelerated evaporation and reduced the volumetric water content relative to plots mulched with CC residues. While growing CCs use soil water and may reduce available moisture for subsequent crops, particularly in semiarid regions, CCs can also maintain or increase soil water content by increasing precipitation capture through increased water infiltration and reduced evaporation. In our study region, precipitation is, in general, adequate for crop production, and thus, use of CCs may not cause water shortage for subsequent crops. However, in regions with limited precipitation such as the semiarid Great Plains, impacts of CCs on soil water storage and yields of subsequent crops deserve further scrutiny. Early termination, selection of appropriate CC species, and other sitespecific management strategies should be developed for the successful use of CCs in semiarid regions.

Impact of surface cover mulch on soil water content and soil temperature regime as well as the impact of these dynamic soil properties on crop yields is well known (Sharratt, 2002). Soil temperature influences several physical, chemical, and biological processes in the soil. It affects seed germination, root growth, evaporation, soil moisture content, microbial processes, nutrient 
cycling, and other processes (van Donk et al., 2004). Our results suggest that, because soil water content and temperature are a function of the amount of surface vegetative cover (Larney et al., 2003), addition of residues to the soil surface cover through CCs can rapidly alter the soil water and temperature dynamics essential to soil processes and agricultural productivity. Crop residue mulch insulates the soil and buffers the abrupt fluctuations of soil temperature (Kladivko, 1994). It regulates the near-surface radiation energy balance and the dynamics of heat exchange between the soil and the atmosphere (Sauer et al., 1998). Increase in surface residue cover with CCs in no-till fields may create different microclimatic conditions favorable for crop production.

Based on the correlation study, principal component analysis (PCA) was performed to group highly correlated soil properties and identify the most crop yield predictive soil parameters. The PCA identified three principal components (PCs) with eigenvalues $>1$ for the $0 \mathrm{~kg} \mathrm{~N} \mathrm{ha}^{-1}$ and four PCs for the $66 \mathrm{~kg} \mathrm{~N} h a^{-1}$ (Table 6). For $0 \mathrm{~kg} \mathrm{~N} \mathrm{ha}^{-1}$, PC1 explained 52\% of the variability and had the highest loading on Proctor density. The PC2 and PC3 had the highest loading on bulk density and volumetric water content at $-33 \mathrm{kPa}$, respectively. The three PCs at $0 \mathrm{~kg} \mathrm{~N}$ ha ${ }^{-1}$ explained $81 \%$ of variance. For $66 \mathrm{~kg} \mathrm{~N} \mathrm{ha}^{-1}$ (Table 6), PC1 explained the largest variance and had the highest loading on total N. The PC2 had the highest loading on water content at -33 and 1,500 kPa, porosity, PC3 on mean weight diameter of aggregates, and PC4 on cone index.

The soil properties with the highest factor loadings under each PC and N rate were used as input for the stepwise multiple regression analysis to develop yield predictive equations (Table 6). The resulting predictive equations were:

For $0 \mathrm{~kg} \mathrm{Nha}^{-1}$ :

Wheat Yield $=4.02-2.02$ (Proctor maximum bulk density); $r^{2}=0.67 ; P=0.001 \quad$ Eq. [1]

Sorghum Yield $=41.91-21.62$ (Proctor maximum bulk density); $r^{2}=0.62 ; P<0.002 \quad$ Eq. [2] 
For $66 \mathrm{~kg} \mathrm{~N} \mathrm{ha}^{-1}$ :

Wheat Yield $=1.88+0.51($ Soil Total $N)+0.46($ MWD $) ; r^{2}=0.77 ; P=0.001 \quad$ Eq. [3]

Equations [1] through [3] indicate that Proctor maximum bulk density was the best predictor of wheat and grain sorghum yield at $0 \mathrm{~kg} \mathrm{~N} \mathrm{ha}^{-1}$, while total $\mathrm{N}$ and mean weight diameter of aggregates (MWD) had the most predictive ability for wheat at $66 \mathrm{~kg} \mathrm{~N} \mathrm{ha}^{-1}$. At this level of $\mathrm{N}$, none of the soil properties measured was a significant predictor for sorghum at the 0.05 probability level. The PCA confirmed the significant and consistent correlation of both soil properties with yields particularly at $0 \mathrm{~kg} \mathrm{~N}^{-1}$ (Fig. 3A-B; Fig 4C-D).

\section{CONCLUSIONS}

Sunn hemp and LMS used as summer CCs in a no-till cropping system rapidly increased wheat and sorghum yields on an Udic Argiustoll. These summer CCs also fixed significant amounts of $\mathrm{N}$ in the soil compared with non-CC plots, suggesting that they can supplement $\mathrm{N}$ especially in cropping systems with limited inorganic $\mathrm{N}$ input. Cover crop-induced changes in soil properties were partly responsible for the increase in crop yield. Changes in soil maximum compactibility, SOC and soil total N concentration, aggregate stability, field soil water content, and soil temperature were strongly related to crop yields. Results suggest CCs increase crop yields and improve soil-crop relationships.

Based on our results, SH and LMS may be potential summer legume CCs for no-till wheatsorghum rotations in the study region. Results also indicate that inclusion of summer legume CCs in no-till systems can reduce $\mathrm{N}$ fertilizer requirements while improving soil physical properties and increasing SOC and N concentration. Overall, summer CCs can be one of the best management practices to diversify and intensify cropping systems, manage $\mathrm{N}$ requirements, 
balance crop production and soil and environmental quality, and contribute to land stewardship

and overall long-term sustainability of agricultural production systems.

\section{REFERENCES}

Andraski, T.W. and L.G. Bundy. 2005. Cover crop effects on corn yield response to nitrogen on an irrigated sandy soil. Agron. J. 97:1239-1244.

Balkcom, K.S. and D.W. Reeves. 2005. Sunn-hemp utilized as a legume cover crop for corn production. Agron. J. 97:26-31.

Blanco-Canqui H., M.M. Mikha, D.R. Presley, and M.M. Claassen. 2011. Addition of cover crops enhances no-till potential for improving soil physical properties. Soil Sci. Soc. Am. J. 75:1471-1482.

Carof, M., S. de Tourdonnet, Y. Coquet, V. Hallaire, and J. Roger-Estrade. 2007. Hydraulic conductivity and porosity under conventional and no-tillage and the effect of three species of cover crop in northern France. Soil Use Manage. 23:230-237.

Cherr, C.M., J.M.S. Scholberg, and R. McSorley. 2006. Green manure as nitrogen source for sweet corn in a warm-temperate environment. Agron. J. 98:1173-1180.

Claassen, M.M. 2009. Effects of late-maturing soybean and sunn hemp summer cover crops and nitrogen rate in a no-till wheat/grain sorghum rotation. Report of Progress 1017. pp. 44-49. Kansas State Univ., Agric. Exp. Stn. and Coop. Ext. Serv., Manhattan, KS. Available at: www.ksre.ksu.edu/library/crpsl2/srp1017.pdf (verified Feb 7, 2011).

Cox, M.S., P.D. Gerard, and D.B. Reynolds. 2005. Selected soil property variability and their relationships with cotton yield. Soil Sci. 170:928-937.

Gregorich, E.G., D.R. Lapen, B.L. Ma, N.B. McLaughlin, and A.J. VandenBygaart. 2011. Soil and crop response to varying levels of compaction, nitrogen fertilization, and clay content. Soil Sci. Soc. Am. J. 75:1483-1492.

Hao, X.M., K. Thelen, and J. Gao. 2010. Effects of soil and topographic properties on spatial variability of corn grain ethanol yield. Agron. J. 102:998-1006.

Jackson, L.E. 2000. Fates and losses of nitrogen from a nitrogen-15-labeled cover crop in an intensively managed vegetable system. Soil Sci. Soc. Am. J. 64:1404-1412.

Kaspar, T.C., D.J. Pulido, T.E. Fenton, T.S. Colvin, D.L. Karlen, D.B. Jaynes, and D.W. Meek. 2004. Relationship of corn and soybean yield to soil and terrain properties. Agron. J. 96:700709.

Kladivko, E.J. 1994. Residue effects on soil physical properties. pp. 123-162. In P. W. Unger (ed.) Managing agricultural residues. Lewis Publishers, Boca Raton, FL. 
Kravchenko, A.N. and D.G. Bullock. 2000. Correlation of grain yield with topography and soil properties. Agron. J. 92:75-83.

Kuo, S. and E.J. Jellum. 2000. Long-term winter cover cropping effects on corn (Zea mays L.) production and soil nitrogen availability. Biolog. Fert. Soils 31:470-477.

Lal, R. 2011. Sequestering carbon in soils of agro-ecosystems. Food Policy. 36:S33-S39.

Larney, F.J., J. Ren, S.M. McGinn, C.W. Lindwall, and R.C. Izaurralde. 2003. The influence of rotation, tillage and row spacing on near-surface soil temperature for winter wheat in southern Alberta. Can. J. Soil Sci. 83:89-98.

Mansoer, Z., D.W. Reeves, and C.W.Wood. 1997. Suitability of sunn hemp as an alternative late-summer legume cover crop. Soil Sci. Soc. Am. J. 61:246-253.

Mulvaney, R.L., S.A. Khan, and T.R. Ellsworth. 2009. Synthetic nitrogen fertilizers deplete soil nitrogen: A global dilemma for sustainable cereal production. J. Environ. Qual. 38:2295-2314.

Olson, K.R., S.A. Ebelhar, and J.M. Lang. 2010. Cover crop effects on crop yields and soil organic carbon content. Soil Sci. 175:89-98.

Powlson, D.S., D.S. Jenkinson, A.E. Johnston, P.R. Poulton, M.J. Glendining, and K.W.T. Goulding. 2009. Comments on "Synthetic nitrogen fertilizers deplete soil nitrogen: A global dilemma for sustainable cereal production". J. Environ. Qual. 749-752.

Rawls, W.J., Y.A. Pachepsky, J.C. Ritchie, T.M. Sobecki, and H. Bloodworth. 2003. Effect of soil organic carbon on soil water retention. Geoderma 116:61-76.

Reddy, K.C., A.R. Soffes, and G.M. Prine. 1986. Tropical legumes for green manure: I. Nitrogen production and the effects on succeeding crop yields. Agron. J. 78:1-4.

SAS Institute. 2011. SAS OnlineDoc 9.1.3. Available at support.sas.com/onlinedoc/913/docMainpage.jsp (verified 20 Jan, 2011). SAS Inst., Cary, NC.

Sauer, T.J., J.L. Hatfield, J.H. Prueger, and J.M. Norman. 1998. Surface energy balance of a corn residue-covered field. Agric. Forest Meteorol. 89:155-168.

Schomberg, H.H., N.L. Martini, J.C. Diaz-Perez, S.C. Phatak, K.S. Balkcom, and H.L. Bhardwaj. 2007. Potential for using sunn hemp as a source of biomass and nitrogen for the Piedmont and Coastal Plains regions of the Southeastern USA. Agron. J. 99:1448-1457.

Sharratt, B.S. 2002. Corn stubble height and residue placement in the northern US Corn Belt Part I. Soil physical environment during winter. Soil Tillage Res. 64:243-252.

van Donk, S.J., E.W. Tollner, J.L. Steiner, and S.R. Evett. 2004. Soil temperature under a dormant bermudagrass mulch: Simulation and measurement. Trans. ASAE 47:91-98.

Wang, Q., W. Klassen, Y. Li, and M. Codallo. 2009. Cover crops and organic mulch to improve tomato yields and soil fertility. Agron. J. 101:345-351. 
Weil, R.R. and F. Magdoff. 2004. Significance of soil organic matter to soil quality and health. pp. 1-43. In F.R. Magdoff and R.R. Weil (eds.) Soil organic matter in sustainable agriculture, CRC Press, New York, USA. 
Table 1. Summary of management of cover crops at Hesston, KS.

\begin{tabular}{|c|c|c|c|c|c|c|}
\hline Year & Cover crop treatments & Tillage & $\begin{array}{c}\text { Planting } \\
\text { date }\end{array}$ & $\begin{array}{l}\text { Seeding } \\
\text { rate } \\
\left(\mathrm{kg} \mathrm{ha}^{-1}\right)\end{array}$ & $\begin{array}{l}\text { Termination } \\
\text { date }\end{array}$ & $\begin{array}{l}\text { Termination } \\
\text { method }\end{array}$ \\
\hline \multirow{3}{*}{$\begin{array}{l}1995 \text { to } \\
1996\end{array}$} & 1. No cover crop & $\mathrm{RT}$ & \multirow{3}{*}{$\begin{array}{l}15 \text { Sept. } \\
1995\end{array}$} & & & ---------- \\
\hline & 2. Hairy vetch terminated early & $\mathrm{RT}$ & & 17 & May 201996 & RT \\
\hline & 3. Hairy vetch terminated late & $\mathrm{RT}$ & & 17 & June 111996 & $\mathrm{RT}$ \\
\hline \multirow{3}{*}{$\begin{array}{l}1997 \text { to } \\
1998\end{array}$} & 1. No cover crop & $\mathrm{RT}$ & & & & ---------- \\
\hline & 2. Hairy vetch terminated by tillage & $\mathrm{RT}$ & \multirow{2}{*}{$\begin{array}{l}17 \text { Sept. } \\
1997\end{array}$} & 22 & May 141998 & RT \\
\hline & $\begin{array}{l}\text { 3. Hairy vetch terminated by } \\
\text { herbicide }\end{array}$ & RT & & 22 & May 131998 & NT \\
\hline \multirow{3}{*}{$\begin{array}{l}1999 \text { to } \\
2000\end{array}$} & 1. No cover crop & RT & \multirow{3}{*}{$\begin{array}{l}8 \text { Oct. } \\
1999\end{array}$} & & & -------- \\
\hline & 2. Hairy vetch terminated by tillage & NT & & 28 & May 82000 & $\mathrm{RT}$ \\
\hline & $\begin{array}{l}\text { 3. Hairy vetch terminated by } \\
\text { herbicide }\end{array}$ & NT & & 28 & May 82000 & NT \\
\hline \multirow{3}{*}{2002} & 1. No cover crop & NT & & & & --------- \\
\hline & 2. Late-maturing soybean & NT & July 5 & 66 & Oct. 14 & NT \\
\hline & 3. Sunn hemp & NT & July 5 & 11 & Sept. 10 & NT \\
\hline \multirow{3}{*}{2004} & 1. No cover crop & NT & & & & --------- \\
\hline & 2. Late-maturing soybean & NT & July 9 & 67 & Oct. 5 & NT \\
\hline & 3. Sunn hemp & NT & July 9 & 11 & Sept. 18 & NT \\
\hline \multirow{3}{*}{2006} & 1. No cover crop & NT & & & & -------- \\
\hline & 2. Late-maturing soybean & NT & Aug. 8 & 67 & Oct. 14 & NT \\
\hline & 3. Sunn hemp & NT & Aug. 8 & 11 & Oct. 14 & NT \\
\hline \multirow{3}{*}{2008} & 4. No cover crop & NT & & & & --------- \\
\hline & 5. Late-maturing soybean & NT & July 3 & 67 & Oct. 21 & NT \\
\hline & 6. Sunn hemp & NT & July 3 & 11 & Sept. 26 & NT \\
\hline
\end{tabular}


Table 2. Planting and harvest dates for winter wheat-sorghum rotation under summer cover crops from 2003 to 2009 at Hesston, KS.

\begin{tabular}{|c|c|c|c|}
\hline \multicolumn{2}{|c|}{ Grain Sorghum } & \multicolumn{2}{|c|}{ Winter Wheat } \\
\hline Planting Date & Harvest Date & Planting Date & Harvest Date \\
\hline June 122003 & Oct. 242003 & Oct. 282003 & June 242004 \\
\hline May 232005 & Sept. 152005 & Oct. 252005 & June 152006 \\
\hline June 62007 & Oct. 32007 & Nov. 32007 & July 12008 \\
\hline June 242009 & Nov. 82009 & & \\
\hline
\end{tabular}


Table 3. Precipitation input on a monthly and annual basis from 2002 to 2009 for the cover crop experiment at Hesston, KS.

\begin{tabular}{|c|c|c|c|c|c|c|c|c|c|}
\hline \multicolumn{10}{|c|}{ Precipitation input (mm) } \\
\hline & 2002 & 2003 & 2004 & 2005 & 2006 & 2007 & 2008 & 2009 & $\begin{array}{c}\text { 30-yr } \\
\text { Average }\end{array}$ \\
\hline January & 36 & 2 & 33 & 78 & 3 & 27 & 6 & 1 & 20 \\
\hline February & 10 & 36 & 25 & 44 & 0 & 12 & 48 & 8 & 27 \\
\hline March & 11 & 76 & 133 & 78 & 72 & 99 & 59 & 56 & 69 \\
\hline April & 106 & 114 & 41 & 38 & 80 & 100 & 91 & 147 & 72 \\
\hline May & 75 & 121 & 59 & 152 & 56 & 229 & 129 & 79 & 123 \\
\hline June & 189 & 72 & 135 & 250 & 103 & 106 & 110 & 134 & 120 \\
\hline July & 54 & 14 & 148 & 89 & 77 & 89 & 90 & 133 & 91 \\
\hline August & 64 & 121 & 62 & 178 & 130 & 70 & 131 & 52 & 98 \\
\hline September & 44 & 116 & 33 & 30 & 30 & 23 & 125 & 109 & 76 \\
\hline October & 168 & 115 & 76 & 29 & 53 & 66 & 109 & 100 & 75 \\
\hline November & 10 & 2 & 48 & 6 & 3 & 5 & 49 & 16 & 43 \\
\hline December & 13 & 35 & 5 & 6 & 43 & 74 & 9 & 18 & 26 \\
\hline Annual & 780 & 824 & 798 & 980 & 649 & 898 & 955 & 852 & 839 \\
\hline
\end{tabular}


Table 4. Plant height and residue yield of two summer cover crops for each rotation cycle at Hesston, KS. Nitrogen fertilizer was applied to main crops consisting of wheat-sorghum rotation.

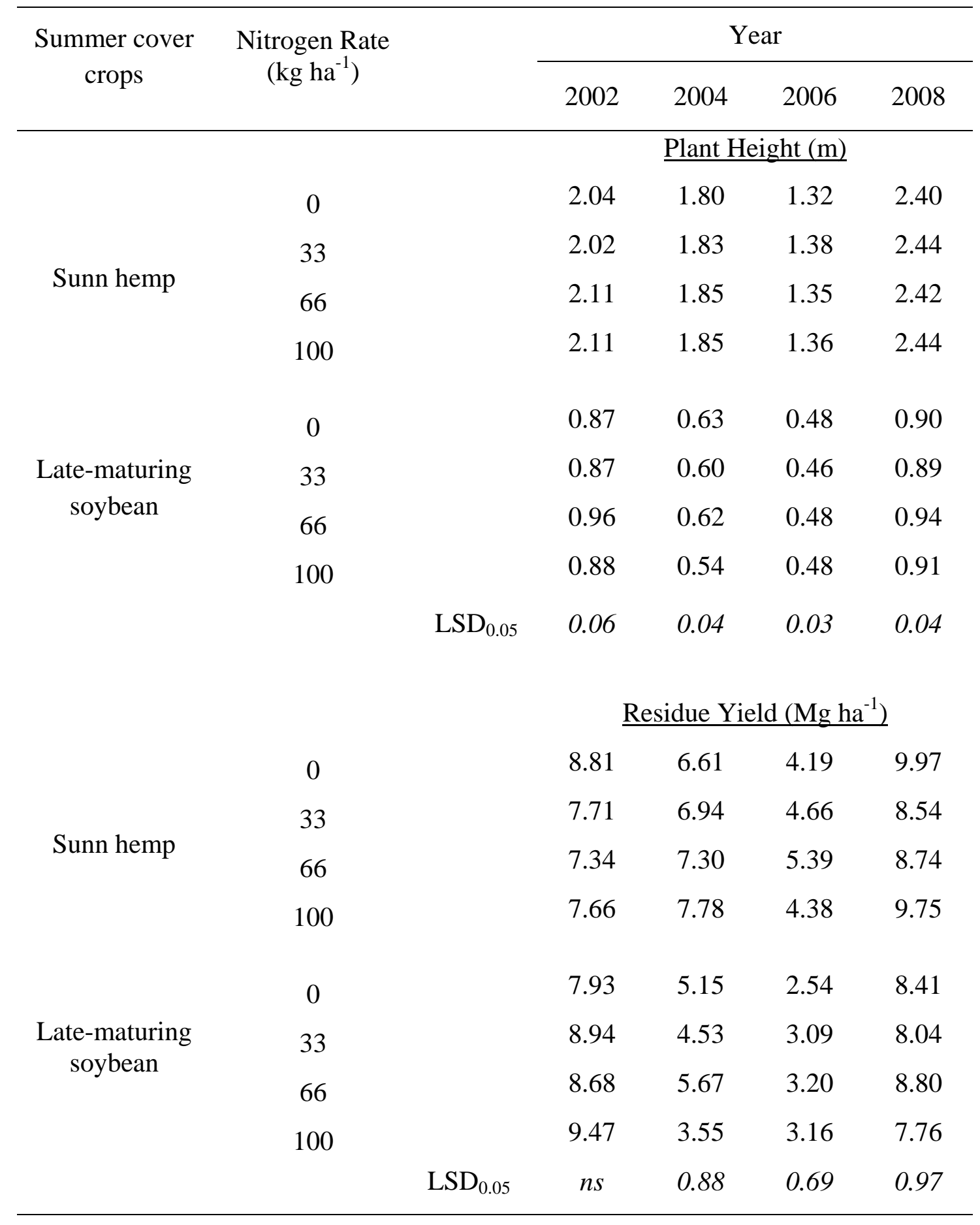


Table 5. Summary of statistical results for treatment effects and interactions for grain sorghum and winter wheat yield as affected by three cover crop treatments and four $\mathrm{N}$ application rates for each rotation cycle at Hesston, KS.

\begin{tabular}{|c|c|c|c|c|c|c|c|}
\hline \multirow[t]{2}{*}{ Treatment } & \multicolumn{4}{|c|}{ Grain Sorghum Yield } & \multicolumn{3}{|c|}{ Winter Wheat Yield } \\
\hline & 2003 & 2005 & 2007 & 2009 & 2004 & 2006 & 2008 \\
\hline & \multicolumn{7}{|c|}{ Fixed Effects $(P>F)$} \\
\hline Treatment & 0.01 & $<0.01$ & $<0.01$ & $<0.01$ & 0.02 & 0.10 & 0.03 \\
\hline N Rate & 0.28 & $<0.01$ & $<0.01$ & $<0.01$ & $<0.01$ & $<0.01$ & $<0.01$ \\
\hline $\begin{array}{l}\text { Treatment } \times \\
\text { N Rate }\end{array}$ & 0.59 & 0.02 & 0.11 & 0.01 & $<0.01$ & 0.64 & 0.16 \\
\hline
\end{tabular}


Table 6. Variance of principal components and loadings on soil properties as a result of the principal component analysis.

\begin{tabular}{|c|c|c|c|c|c|c|c|c|c|}
\hline & & $\underline{0 \mathrm{~kg} \mathrm{~N}}$ & $a^{-1}$ & & & & $\underline{66 \mathrm{~kg}}$ & $\mathrm{~J} \mathrm{ha}^{-1}$ & \\
\hline Variable & $\underline{\text { PC1 }}$ & $\underline{\text { PC2 }}$ & $\underline{\mathrm{PC} 3}$ & $\underline{\mathrm{CE}}$ & $\underline{\text { PC1 }}$ & $\underline{\mathrm{PC} 2}$ & $\underline{\text { PC3 }}$ & $\underline{\mathrm{PC} 4}$ & $\underline{\mathrm{CE}}$ \\
\hline Eigenvalue & 6.76 & 2.45 & 1.25 & & 5.36 & 2.20 & 1.78 & 1.31 & \\
\hline $\begin{array}{l}\text { Proportion of the total } \\
\text { variance }\end{array}$ & 0.52 & 0.19 & 0.10 & & 0.41 & 0.17 & 0.14 & 0.10 & \\
\hline Cumulative variance & 0.52 & 0.71 & 0.81 & & 0.41 & 0.58 & 0.72 & 0.82 & \\
\hline Bulk density ( $\left.\mathrm{Mg} \mathrm{m}^{-3}\right)$ & -0.19 & -0.88 & 0.07 & 0.82 & -0.36 & -0.75 & 0.03 & -0.27 & 0.76 \\
\hline Macroaggregates $\left(\mathrm{kg} \mathrm{kg}^{-1}\right)$ & 0.76 & 0.53 & 0.33 & 0.95 & 0.32 & 0.31 & 0.87 & -0.06 & 0.96 \\
\hline $\begin{array}{l}\text { Mean Weight Diameter of } \\
\text { Aggregates (mm) }\end{array}$ & 0.58 & 0.61 & 0.24 & 0.77 & 0.02 & 0.20 & 0.93 & -0.10 & 0.91 \\
\hline Cone Index (MPa) & -0.18 & 0.22 & -0.70 & 0.57 & 0.19 & -0.13 & -0.09 & 0.87 & 0.81 \\
\hline $\begin{array}{l}\text { Proctor Maximum Bulk } \\
\text { Density }\left(\mathrm{Mg} \mathrm{m}^{-3}\right)\end{array}$ & -0.95 & -0.06 & 0.03 & 0.91 & -0.77 & -0.23 & 0.24 & -0.18 & 0.74 \\
\hline $\begin{array}{l}\text { Log Saturated Hydraulic } \\
\text { Conductivity }\left(\mathrm{mm} \mathrm{h}^{-1}\right)\end{array}$ & 0.17 & 0.61 & 0.05 & 0.40 & 0.46 & -0.13 & -0.01 & -0.69 & 0.70 \\
\hline Porosity $\left(\mathrm{m}^{3} \mathrm{~m}^{-3}\right)$ & 0.13 & 0.58 & 0.75 & 0.91 & 0.03 & 0.90 & 0.19 & -0.09 & 0.86 \\
\hline $\begin{array}{l}\text { Volumetric Water Content } \\
\text { at }-33 \mathrm{kPa}\left(\mathrm{m}^{3} \mathrm{~m}^{-3}\right)\end{array}$ & 0.01 & 0.33 & 0.88 & 0.89 & 0.06 & 0.86 & 0.33 & -0.21 & 0.90 \\
\hline $\begin{array}{l}\text { Volumetric Water Content } \\
\text { at }-1,500 \mathrm{kPa}\left(\mathrm{m}^{3} \mathrm{~m}^{-3}\right)\end{array}$ & 0.56 & 0.34 & -0.58 & 0.76 & 0.21 & 0.79 & 0.01 & 0.02 & 0.66 \\
\hline Field Soil Water Content & 0.91 & 0.27 & -0.01 & 0.90 & 0.59 & -0.21 & 0.64 & 0.21 & 0.84 \\
\hline Daytime Soil Temperature & -0.88 & -0.18 & 0.01 & 0.84 & -0.71 & -0.07 & -0.42 & 0.08 & 0.69 \\
\hline Soil Organic Carbon $\left(\mathrm{g} \mathrm{kg}^{-1}\right)$ & 0.94 & 0.17 & 0.20 & 0.95 & 0.82 & 0.37 & 0.28 & -0.05 & 0.89 \\
\hline Soil Total Nitrogen $\left(\mathrm{g} \mathrm{kg}^{-1}\right)$ & 0.92 & 0.19 & 0.06 & 0.89 & 0.84 & 0.22 & 0.34 & -0.17 & 0.91 \\
\hline
\end{tabular}




\section{FIGURE CAPTIONS}

Figure 1. Mean grain sorghum yield as affected by three cover crop treatments for 2003, 2005, 2007, and 2009. The error bars represent LSD values to compare cover crop treatment effects on yield within each level of $\mathrm{N}$ application.

Figure 2. Mean winter wheat yield as affected by three cover crop treatments for 2004, 2006, and 2008. The error bars represent LSD values to compare cover crop treatment effects on yield within each level of $\mathrm{N}$ application.

Figure 3. Mean soil total $\mathrm{N}$ for each cover crop treatment (A) and for each level of $\mathrm{N}$ application (B) in the 0 - to $7.5-\mathrm{cm}$ soil depth. There were no differences in soil total $\mathrm{N}$ below $7.5 \mathrm{~cm}$ soil depth. Bars accompanied by different lowercase letters are significantly different.

Figure 4. Relationship of grain sorghum and winter wheat yield with Proctor maximum bulk density (A and B) and mean weight diameter of aggregates (C and D) at two levels of $\mathrm{N}$ application (0 and $66 \mathrm{~kg} \mathrm{~N} \mathrm{ha}^{-1}$ ).

Figure 5. Relationship of grain sorghum and winter wheat yield with soil organic carbon (A and B) and soil total $\mathrm{N}$ (C and D) at two levels of $\mathrm{N}$ application (0 and $66 \mathrm{~kg} \mathrm{~N} \mathrm{ha}^{-1}$ ).

Figure 6. Relationship of grain sorghum and winter wheat yield with field soil water content (A and $\mathrm{B}$ ) and daytime soil temperature measured in spring (C and D) at two levels of $\mathrm{N}$ application (0 and $66 \mathrm{~kg} \mathrm{~N} \mathrm{ha}^{-1}$ ). 

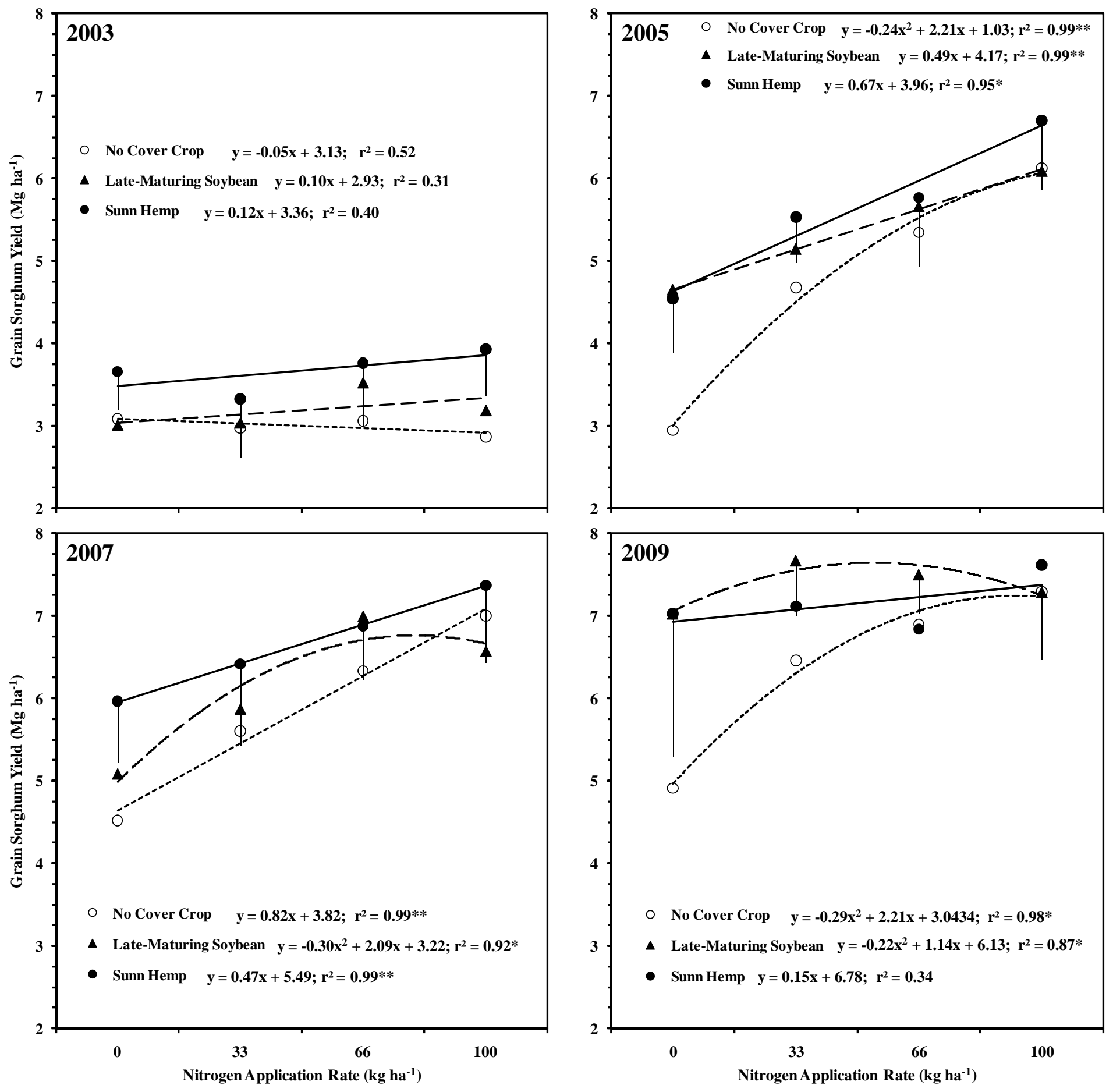

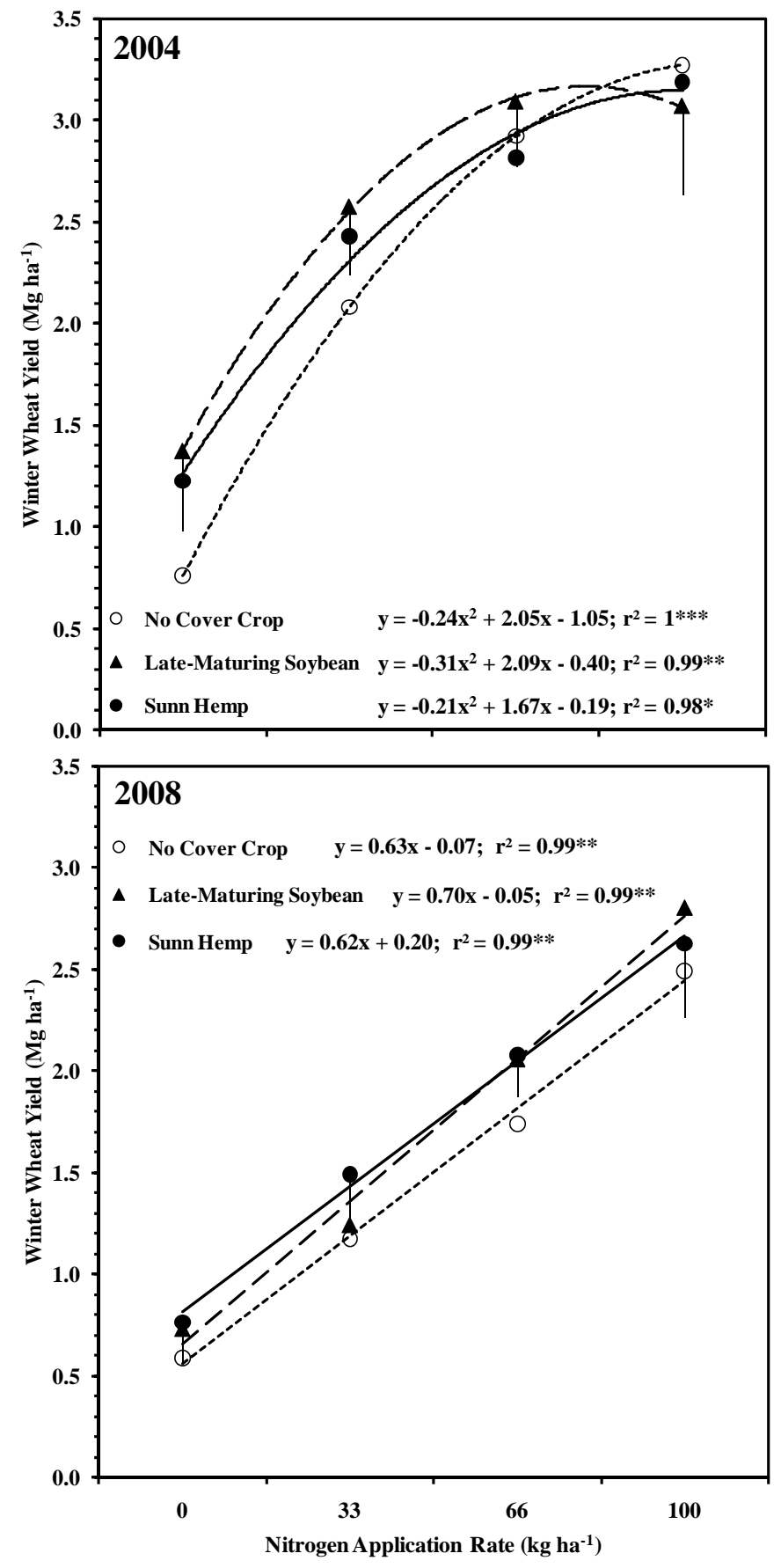

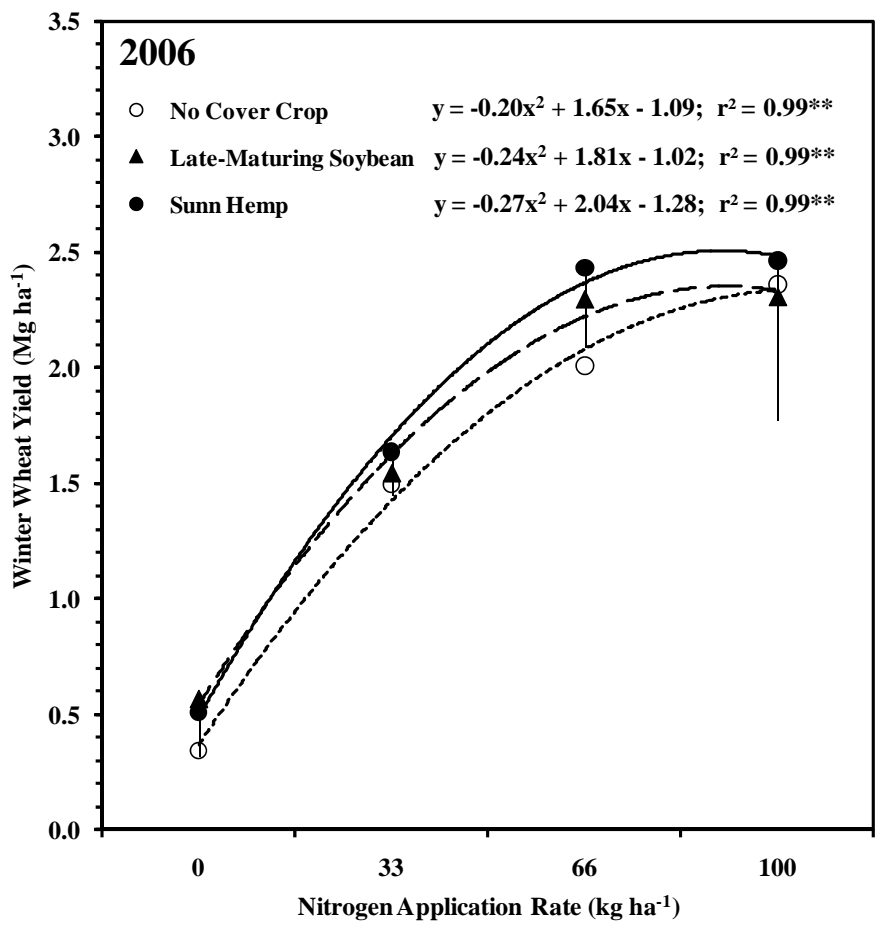



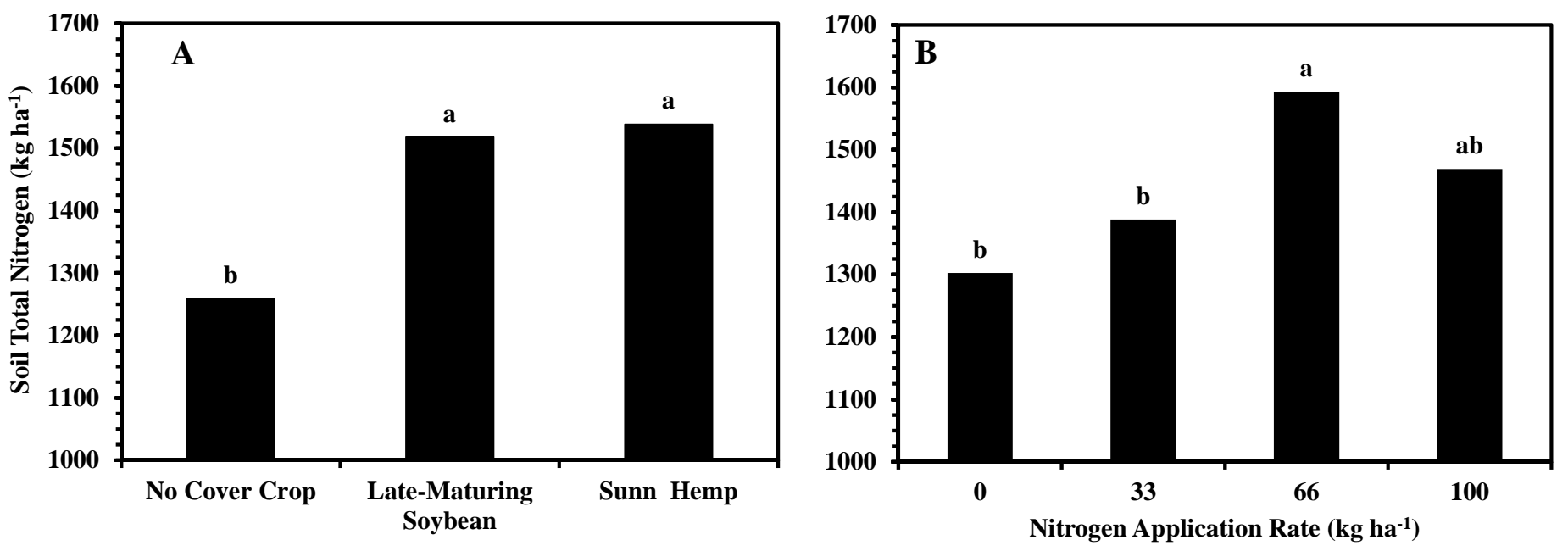

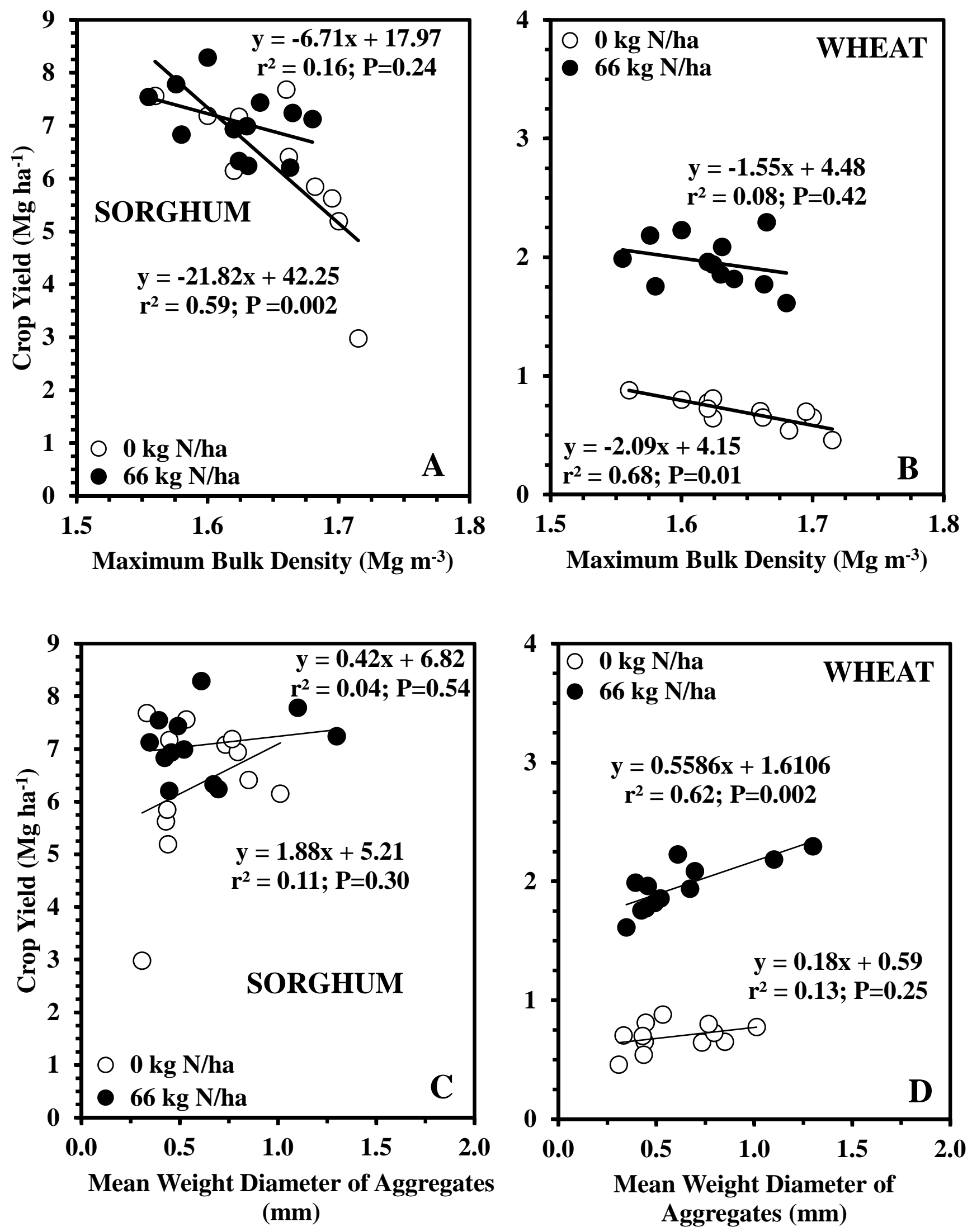

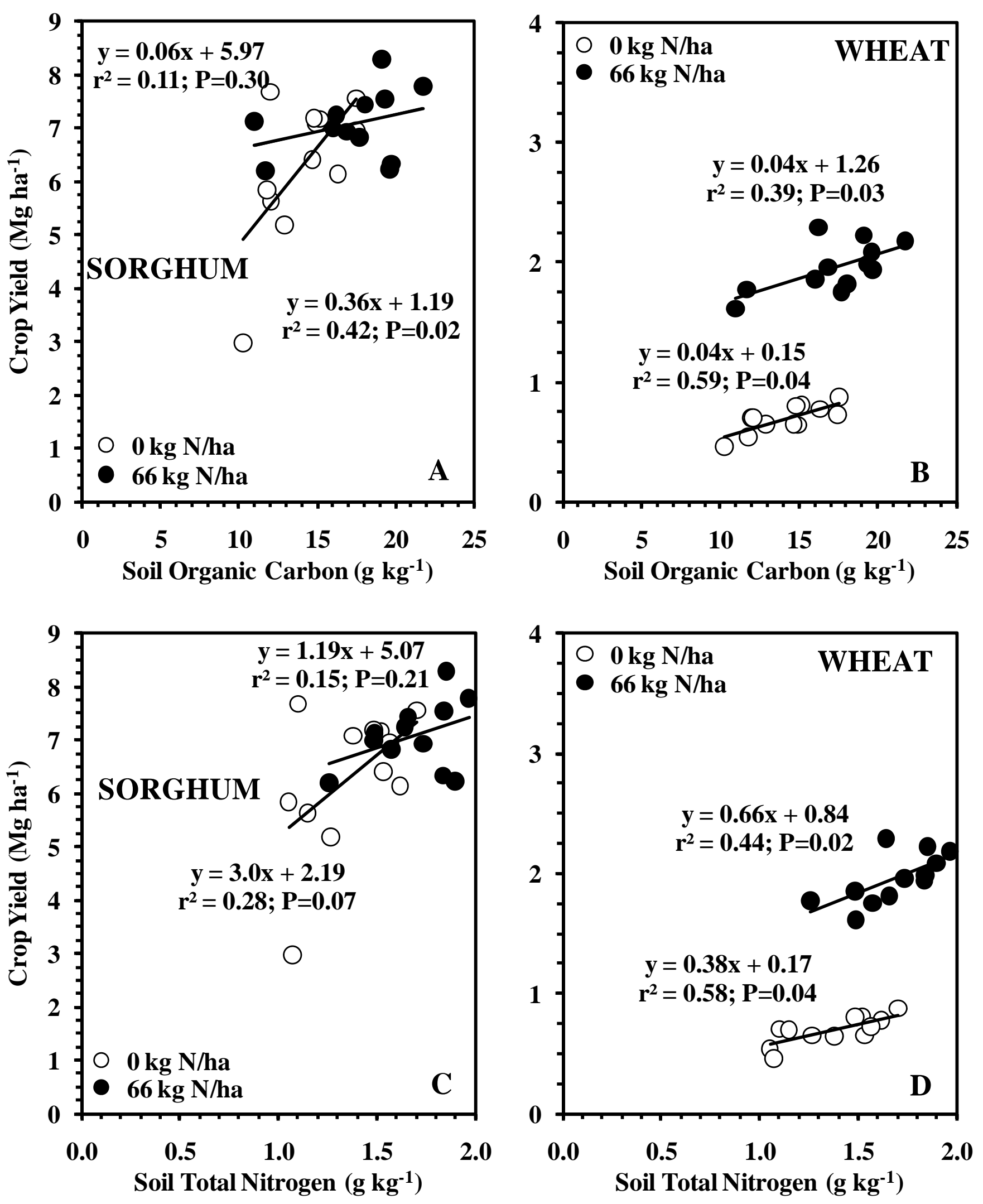


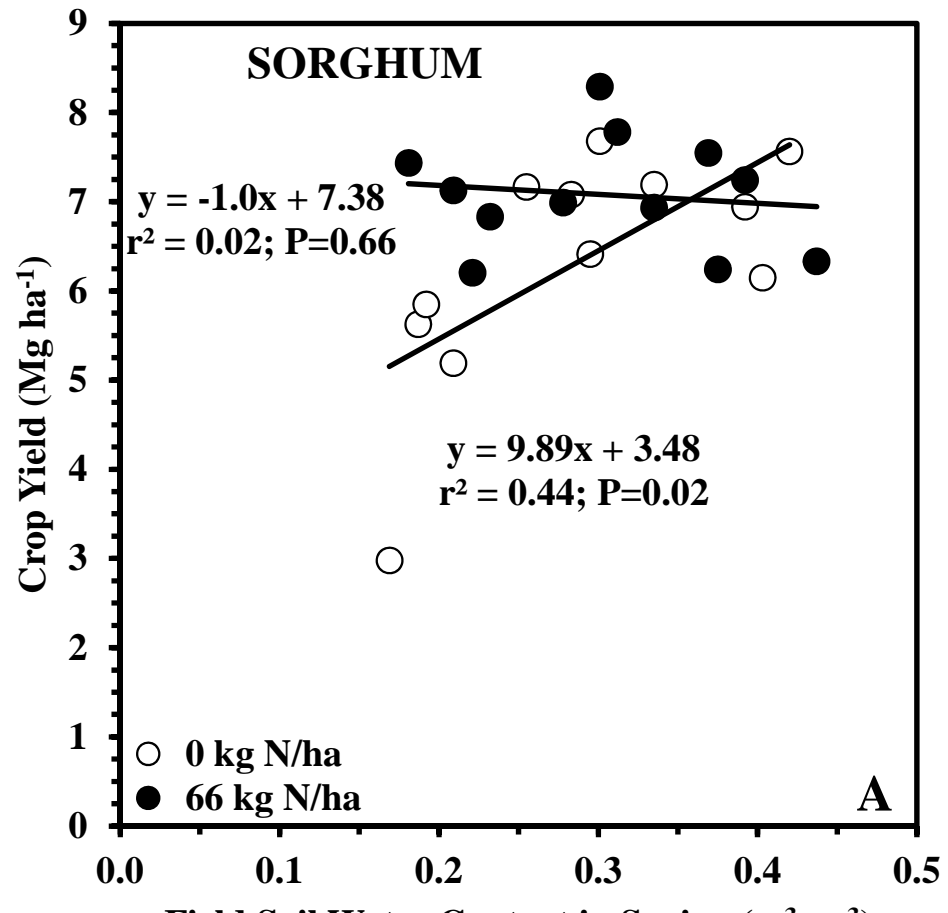

Field Soil Water Content in Spring $\left(\mathrm{m}^{3} \mathrm{~m}^{-3}\right)$

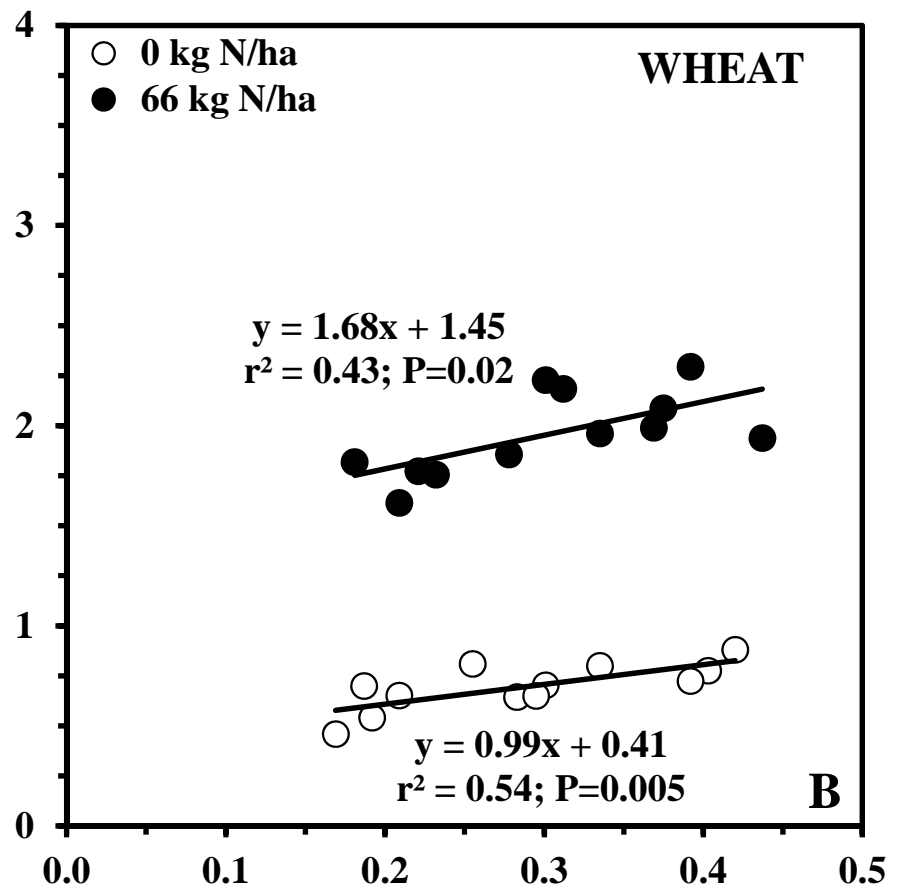

Field Soil Water Content in Spring $\left(\mathrm{m}^{3} \mathrm{~m}^{-3}\right)$
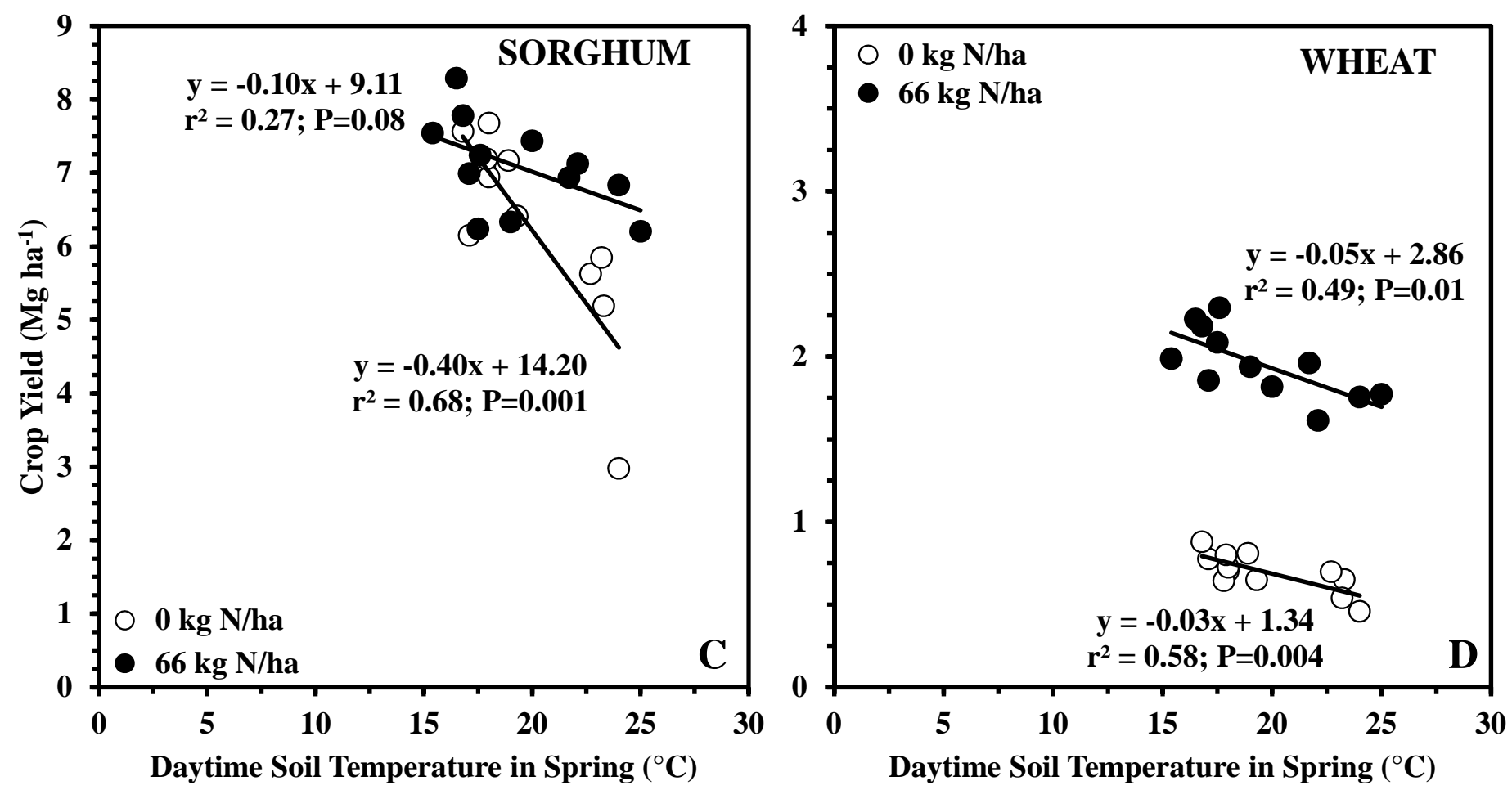